\title{
RESPONSABILIDADE EMPRESARIAL E GREENWASHING: IMPLICAÇÕES
} ÉTICAS E JURÍDICAS.

\author{
Helder Leonardo de Souza Goes ${ }^{1}$ \\ Gabriela Maia Rebouças ${ }^{2}$
}

\section{RESUMO}

Este artigo propõe uma análise das implicações éticas e jurídicas do greenwashing, maquiagem verde ou publicidade verde, confrontando a responsabilidade empresarial. Grandes grupos econômicos utilizam a imagem de protetores do meio ambiente para valorizar seus produtos, fidelizando seus consumidores que compartilham a postura ética de responsabilidade com o meio ambiente e práticas sustentáveis. Com base em pesquisas bibliográficas e documentais, com ênfase para um estudo analítico dos argumentos jurídicos e filosóficos que classificam tais práticas, este estudo evidencia que uma cultura empresarial responsável é compatível com a defesa econômica dos direitos humanos.

Palavras-Chave: Greenwashing, Responsabilidade Empresarial, Ética.

\section{CORPORATE RESPONSIBILITY AND GREENWASHING: ETHICAL AND LEGAL IMPLICATIONS.}

\begin{abstract}
This article proposes an analysis of the ethical and legal implications of greenwashing, green makeup or green advertising, confronting corporate responsibility. Large economic groups use the image of environmental protectors to value their products, retaining their consumers who share the ethical stance of responsibility towards the environment and sustainable practices. Based on bibliographical and documentary research, with an emphasis on an analytical study of the legal and philosophical arguments that classify such practices, this study shows that a responsible corporate culture is compatible with the economic defense of human rights.
\end{abstract}

Keywords: Greenwashing, Corporate Responsibility, Ethics.

\section{Introdução}

O presente trabalho visa apresentar uma análise jurídica e filosófica do greenwashing, propondo uma discussão sobre a necessidade de regulamentação e de efetiva responsabilização de empresários. O greenwashing, também conhecido como falso marketing verde ou maquiagem verde, consiste na utilização de uma imagem de proteção ambiental que

\footnotetext{
${ }^{1}$ Mestrando em Direitos Humanos pela Universidade Tiradentes - UNIT; e-mail: helderlsgoes@ gmail.com.

${ }^{2}$ Doutora em Direito pela UFPE. Pós Doutora pelo CES-Coimbra 2015/2016. Docente no Mestrado em Direitos Humanos UNIT/SE e no Mestrado em Sociedade, Tecnologias e Políticas Públicas UNIT/AL. E-mail: gabriela_maia@unit.br
} 
não corresponde à verdade, oferecendo ao consumidor um produto/serviço que supostamente contribuiria para a proteção do meio ambiente quando na verdade isso não ocorre.

Tal ação se dirige ao consumidor que, preocupado com o meio ambiente, se dispõe a gastar um pouco mais ou simplesmente escolher um produto/serviço de um empresário que apresenta o mesmo ideal.

Nesse ponto ocorrem duas ofensas: por um lado, ofensa ao meio ambiente, já que as práticas empresariais, sejam por suas tecnologias, sejam por seus procedimentos ou utilização de recursos, são incompatíveis com o desenvolvimento sustentável; por outro lado, ofende o consumidor, oferecendo um produto que não corresponde ao que está sendo vendido e viola a dimensão jurídica e ética desta relação, descumprindo o dever de informação e boa-fé.

Como fundamentação jurídica, este trabalho evidencia a responsabilidade empresarial que decorre da função social da empresa, dever de proteção a todos os atores envolvidos na atividade empresarial, bem como do meio ambiente. Neste sentido, vale ponderar acerca da possibilidade de conferir ao meio ambiente a categoria de sujeito de direitos e as consequências desse reconhecimento diante da prática do greenwashing, posto que a responsabilidade através da publicidade enganosa tem como vítima o consumidor e no caso do falso marketing verde, além do consumidor em seus interesses individuais e coletivos, a concorrência empresarial e o próprio meio ambiente, do ponto de vista do reconhecimento dos direitos transindividuais difusos e coletivos.

Este trabalho se apresenta metodologicamente como um estudo analítico tanto da legislação brasileira vigente quanto dos argumentos que sustentam a interpretação desta prática, seja do ponto de vista ético ou jurídico, utilizando da técnica de pesquisa bibliográfica e documental, incluindo análise de jurisprudência.

Dentre os objetivos da pesquisa incluem-se as formas de evitar o greenwashing, quais mecanismos já existem e como efetivá-los, comprometendo-se com uma cultura empresarial responsável e compatível com a defesa econômica dos direitos humanos.

\section{GREENWASHING E PRÁTICAS EMPRESARIAIS: UMA APROXIMAÇÃO}

Atualmente a proteção ao meio ambiente ecologicamente equilibrado tem ganhado cada vez mais espaço na sociedade. Por conta disso, adotar uma postura de proteção ambiental tem sido uma forma de agregar valor à atividade empresarial. 
Assim, discute-se a responsabilidade empresarial quando o empresário apresenta diversas condutas de proteção ambiental, contudo não as realiza de fato, configurando a prática denominada greenwashing. Tal conduta seria apenas uma forma de publicidade enganosa ou trata-se de prática mais grave ou que padece de regulamentação?

\subsection{Conceito de greenwashing}

O termo greenwashing foi criado pelo Greenpeace, podendo ser traduzido como "dar um banho de verde", o greenwashing toma pra si vantagens ecológicas, adotando um discurso verde quando não há uma prática por trás dele, como define Araújo (2007)

Greenwashing é um termo em língua inglesa usado quando uma empresa, ONG, ou mesmo o próprio governo, propaga práticas ambientais positivas e, na verdade, possui atuação contrária aos interesses e bens ambientais. Tratase do uso de ideias ambientais para construção de uma imagem pública positiva de "amigo do meio ambiente" que, porém, não é condizente com a real gestão, negativa e causadora de degradação ambiental. O Greenwashing tem sido uma prática de gestão (nociva, digase de passagem) muito adotada por empresas ligadas a diversos ramos da atividade econômica (ARAÚJO, 2007).

Não se pode confundir o conceito de Greenwashing com Ecopropaganda. Segundo Ferreira (2013, p.32) “(...) entende-se como ecopropaganda ou propaganda verde a comunicação voltada a exploração de discursos formatados a favor da promoção da responsabilidade ambiental corporativa (...)”. Ou seja, o greenwashing utiliza uma falsa propaganda porque os discursos veiculados acerca dos produtos e suas qualidades como produto verde são falsos.

Não se deve, portanto, condenar toda e qualquer ecopropaganda, mas apenas aquela que corresponde a uma dissimulação ou maquiagem. Do ponto de vista do resultado, enquanto no greenwashing existe uma prática que utiliza o discurso de proteção ambiental para obter uma vantagem econômico indevida, na ecopropaganda existe uma real preocupação com a responsabilidade ambiental que seja compatível com o ganho econômico.

A ecopropaganda é uma das formas pelas quais se tenta conscientizar a sociedade da prática de greenwashing e, assim, procura-se evitá-lo.

\subsection{A Teoria da Empresa, sua Função Social e a prática do Greenwashing.}


As implicações das práticas empresariais devem ser vistas à luz da concepção mais moderna de empresa, que não pode concebe-la fora de uma cultura de direitos e garantias constitucionais. Ou seja, para melhor entendimento da Responsabilidade Empresarial é importante compreender a extensão da teoria da empresa, especialmente em relação à sua função social.

Ulhoa (2014, p. 35) faz uma análise histórica da criação da teoria da empresa, e aponta Alberto Asquini como o propositor da teoria em 1942. Para Asquini, a Empresa deve ser entendida como um fenômeno econômico poliédrico, desdobrando-se em quatro perfis: Subjetivo, Objetivo, Funcional e Corporativo.

O primeiro perfil é o Perfil Subjetivo, ou seja, apresenta a figura do Empresário, a pessoa que exerce (concebe e lidera) a empresa. Trata-se de conceito amplo e elástico, capaz de abranger figuras que só viriam a existir no futuro, diferente da teoria dos atos de comércio que apresentava um rol taxativo.

O segundo perfil é o Perfil Funcional, apresentando a atividade exercida pelo empresário, o produto ou o serviço explorado economicamente pelo empresário. Ainda sobre o Perfil Funcional, destaca Alejarra (2014):

(...) Atividade econômica organizada refere-se à atividade da empresa, ou seja, empresário é o exercente profissional de uma atividade, então empresa é uma atividade. É atividade empresarial econômica, pois tem como objetivo o lucro, nenhuma atividade econômica se mantém sem lucratividade no regime capitalista. Por outro lado, é organizada, pois explora a produção, a circulação de bens ou serviços, levando em consideração os quatro fatores de produção: capital, mão-de-obra, insumos e tecnologia. (ALEJARRA, 2014)

O perfil Objetivo, também previsto pelo código civil em seu artigo 1.142, considera o Estabelecimento Empresarial, a saber, o meio pelo qual o empresário exerce empresa.

Ao falar em organização dos bens que compõem o estabelecimento, o legislador se refere ao capital intelectual, ou seja, o saber fazer que trouxesse êxito à atividade empresarial e que acarreta a valorização do estabelecimento empresarial. Tal fenômeno é conhecido como Aviamento $^{3}$.

Até então, os três primeiros perfis dizem respeito à estrutura própria da relação empresarial que envolve sujeito, objeto e ações, referindo-se a elementos concretos da

\footnotetext{
${ }^{3} \mathrm{O}$ valor do estabelecimento empresarial tem um valor superior ao da reunião de bens que o compõe, isso ocorre pela soma do valor relacionado ao capital intelectual aplicado.
} 
atividade empresarial, o empresário, o estabelecimento empresarial e a empresa (atividade explorada).

A nosso ver, o posicionamento mais adequado é aquele referido por Tomazette (2002), o qual apresenta uma crítica à teoria de matriz italiana:

Esse modo de entender a empresa já está superado, porquanto não representa o estudo teórico da empresa em si, mas apenas demonstra a imprecisão terminológica do Código italiano, que confunde a noção de empresa com outras noções. Todavia, com exceção do perfil corporativo que reflete a influência de uma ideologia política, os demais perfis demonstram três realidades intimamente ligadas, e muito importantes na teoria da empresa, a saber, a empresa, o empresário e o estabelecimento. (TOMAZETTE, 2002)

A crítica supracitada se baseia no fato da teoria da empresa não ter fundamentos jurídicos, o que dificulta a análise jurídica de tais institutos. Por vezes o próprio legislador confunde os conceitos de Empresário, Estabelecimento e Empresa.

O Perfil Corporativo, que mais se assemelha a um princípio, traz a ideia de que o empresário, a clientela, os empregados e todos envolvidos na atividade empresarial fazem parte de um núcleo que deve trazer benefícios para todos.

A este perfil, trazemos a crítica de Ulhoa que trata o perfil corporativo como uma utopia, e em tom de crítica aponta que: “(...) O perfil corporativo, por sua vez, sequer corresponde a algum dado de realidade, pois a ideia de identidade de propósitos a reunir na empresa proletários e capitalistas apenas existe em ideologias populistas de direita, ou totalitárias (como facista, que dominava a Itália na época) (...)” (ULHOA, 2014, p. 35)

As tensões trazidas por Ulhoa em sua crítica ao perfil coorporativo não devem ser um empecilho para que se reconheça que, dentre todos os quatro perfis, é o que mais potencial tem para enfrentar a realidade da atividade empresarial hoje, calcada que está num capitalismo neoliberal. Certamente, o perfil coorporativo de que se fala hoje, muito difere daquele perfil histórico trazido por Tomazette (2002), de forma que se desenvolve não apenas em regimes fascistas ou populistas, mas também em contextos de democracias liberais.

Nesse ponto, é necessário analisar influência da pesquisa de Stone (1988), o qual apresenta a importância de se conferir ao meio ambiente a prerrogativa de sujeito de direitos. Ora, ao reconhecer então que a função social da empresa somente se faz presente com a proteção ambiental, reconhecer a natureza como um dos atores envolvidos na atividade empresarial, intensifica-se ainda mais a responsabilidade empresarial pela prática de greenwashing. 
A partir desse perfil, o compromisso com os clientes consumidores fica mais configurado, exigindo que a atividade empresarial não possa se descolar das pessoas reais, físicas, existentes e que suportam diretamente as consequências da própria atividade empresarial: empregados, gestores e clientes.

Desta forma, o perfil corporativo representa uma possibilidade de compreensão da empresa que tem uma grande afinidade com a ideia do capitalismo humanista:

“[...] o capitalismo precisa ser salvo dos capitalistas neoliberais. Uma resposta deve ser dada a eles, e a melhor resposta é a humanização da economia de mercado, deslocando deontologicamente o capitalismo neoliberal: do seu ser - que corresponde ao estado da natureza, selvagem e desumano - para o seu dever-ser da concretização multidimensional dos direitos humanos mediante a universal dignificação da pessoa humana.". (BALERA; SAYEG, 2011, p. 25).

Diante disso, entendemos que o capitalismo não pode ser totalmente livre e precisa de um eficiente sistema de controle para que seja atingido o bem-estar social. Este sistema de controle passa pela iniciativa estatal, mas também deve haver uma conscientização da sociedade e uma cobrança aos setores privados para que não coloquem o interesse patrimonial acima da dignidade de outro ser humano.

Nesse toar, é interessante observar, segundo Campos e Ardisson (2012), que a teoria da empresa não surgiu só por conta da pouca abrangência da teoria dos atos de comércio, mas resultado de um período histórico de transformação social, buscando articular classes sociais historicamente antagônicas. Os interesses individuais devem buscar um ponto de equilíbrio com os interesses coletivos, a iniciativa privada não pode se sobrepor aos direcionamentos do espaço público, ou seja, se por um lado, em qualquer sistema capitalista (liberal ou neoliberal), a busca e a manutenção da propriedade privada continuam protegidas, é preciso que, numa perspectiva do capitalismo humanista, também atendam ao bem social, relativizando a lógica individualista.

Portanto, a ideia do capitalismo humanista oferece fundamentos para a compreensão da função social da empresa. Por isso, no perfil corporativo da Teoria da Empresa é justamente a limitação do capitalismo e o seu direcionamento para a proteção dos direitos de primeira, segunda e terceira dimensões que garantem legitimidade à atividade empresarial.

Com isto, o Princípio da Função Social da Empresa ganha destaque e centralidade em relação à obtenção de lucro puro e simples, tornando-se um dos princípios mais importantes do direito empresarial, que conduz a atividade empresarial como um todo. 
Neste ponto, é sempre importante reconhecer que a Constituição Federal de 1988, ao se referir à livre iniciativa e à garantia da dignidade da pessoa humana, permite-nos extrair a ideia da função social da empresa, corroborando o entendimento que a atividade empresarial torna-se responsável também pelo bem-estar de todos.

Desta forma, na lógica que justifica o sistema capitalista, a empresa exerce um papel importante no desenvolvimento humano, posto que, como já dito anteriormente, ao atender à função social, a empresa deve desenvolver economicamente a região em que é exercida, da mesma forma que funciona como um gerador/distribuidor de riquezas.

Portanto, a prática de greenwashing afronta diretamente a função social da empresa, e com isso a própria legitimação do sistema capitalista. Ela desequilibra os valores constitucionais que buscam compatibilizar uma cultura de direitos humanos com a geração de riquezas e desenvolvimento econômico.

\subsection{Responsabilidade do Empresário pelo Greenwashing}

Atualmente as sociedades direcionadas para o desenvolvimento demandam uma nova forma de exercer atividade empresarial baseada não só no lucro, mas de forma que atenda a função social da empresa em sua plenitude. As escolhas por práticas ilícitas ou antiéticas estão situadas no espaço de responsabilização dos empresários e não podem ser justificadas, sequer em tese, muito menos na prática, como uma atitude esperta ou natural da atividade ${ }^{4}$.

Em nenhuma configuração a adoção de uma maquiagem verde está justificada. $\mathrm{O}$ empresário que supõe que uma das estratégias viáveis é vender a imagem de protetor do meio ambiente, criando a sensação no consumidor de que este está gastando um pouco mais para adquirir um produto que contribua para a sustentabilidade, sem que seu produto ou atividade suportem ações que de fato possam ser reconhecidas como sustentáveis é sempre uma prática nefasta e temerária. Evidentemente, esta estratégia ofende o princípio da livre concorrência,

\footnotetext{
${ }^{4}$ Curioso é perceber que até argumentos da biologia evolucionista podem ser usados para naturalizar comportamentos que, pela compreensão mais básica das condições culturais, jamais estão fora do campo de liberdade e possibilidade de ação. É o caso de se levantar a proposta de Dawkins (1979), segundo quem todo ser vivo possui o "gene egoísta", ou seja, o instinto de sobrevivência que faz com que cada ser vivo venha a adotar a estratégia que lhe melhor aprouver no sentido de lograr êxito. Ora, a moral que me faz pensar estrategicamente nesta ou naquela ação não é genética. Uma compreensão moral compatível com uma cultura de direitos humanos me diz que, na minha busca por êxito, o meu 'gene egoísta' pode se manifestar na adoção de práticas lícitas, imunizando a empresa contra penalizações, fidelizando clientes e fortalecendo minha marca.
} 
bem como ofende o dever de informação estabelecido na no código do consumidor, em seu artigo 30.

Para Fabriani, Oliveira e Pereira (2010) essa nova forma de exercer atividade empresarial, responsável e incorporada a uma cultura de direitos humanos, surge a partir de uma demanda social, fazendo com que o empresário incorpore "(...)em todas as etapas o compromisso com a responsabilidade social e ambiental. Além disso, os resultados das ações desta nova ética de negócios devem ser comunicados à sociedade, assegurando a transparência da atuação empresarial(...)" (PEREIRA, 2010, p. 11).

Como consequência de uma sociedade cada vez mais consciente sobre a importância da proteção ao meio ambiente, a postura de proteção ambiental por parte dos empresários se torna um agregador de valor:

(...) Com a crescente valorização da responsabilidade social e ambiental das empresas, fica evidente que para muitas organizações sustentabilidade ainda é assunto para a assessoria de imprensa conseguir divulgação por meio de matérias espontâneas. Conhecendo o interesse que o tema desperta e, desejando retorno de credibilidade que a matéria oferece, muito superior ao que um anúncio gera, algumas organizações acabam por distorcer verdades, dando destaques muito maiores do que mereceriam, e praticando o chamado greenwashing. (PEREIRA, 2010, p. 16).

Por isso, há uma forte relação entre a função social da empresa, o perfil corporativo e o capitalismo humanista, considerando

Logo, no tocante ao capitalismo, que é baseado na liberdade, evidencia-se a missão dos direitos humanos: incidir em sua multidimensionalidade, sob a perspectiva de adensamento, para reconhecê-lo e a ela agregar igualdade e fraternidade (BALERA; SAYEG, 2011, p. 34).

Portanto, a responsabilidade do empresário pela maquiagem verde não pode ser atenuada, nem relativizada por nenhuma justificativa natural ou de mercado. Ela sempre estará no campo de liberdade de escolha do gestor e da empresa, na forma como escolhe lidar com seus produtos e mercado consumidor. É necessário que fiquem claras, o que se objetiva neste artigo, as implicações jurídicas e éticas de tais práticas, situando-as, seja no campo do direito ou da filosofia, entre as ações que exigem responsabilização.

\section{CONSEQUÊNCIAS DO GREENWASHING NO CAMPO JURÍDICO E FILOSÓFICO}


Neste tópico, passa-se a elencar as principais consequências tanto no campo jurídico quanto filosófico da adoção da maquiagem verde.

Juridicamente, a prática do greenwashing se assemelha à propaganda enganosa, entretanto suas consequências atingem proporções maiores. Como já disposto anteriormente, há o desrespeito à função social da empresa. Ademais, tendo em vista que a ideia do consumo consciente faz com que o consumidor utilize como um dos critérios de escolha de sua compra a proteção ao meio ambiente, resta evidente a quebra do dever de boa-fé.

Neste sentido,

(...) constata-se que as estratégias discursivas desenvolvidas pelas organizações para conectar intimamente o consumidor ao discurso ambiental exposto podem ser abordadas de várias formas. Além disso, compreende-se que a maquiagem verde, além de induzir o consumidor a falsas conclusões em relação as suas escolhas, tem como característica também distorcer a realidade em benefício da organização, construindo uma imagem pública sólida, característica bastante observada pelos consumidores e almejada pelas empresas. (FIALHO, MARQUESAN E SOUZA, 2015, p. 6-7).

E, consequentemente, verifica-se que a prática também acaba desobedecendo a livre concorrência, pilar do sistema empresarial capitalista previsto na Constituição Federal/88.

Além de uma exegese constitucional principiológica, e da ilicitude frente ao código do consumidor, os tribunais também têm sido chamados a se manifestar sobre a questão.

Em 2013 o Supremo Tribunal Federal julgou ação (MI 4766 DF) sob a relatoria do Ministro Gilmar Mendes, cuja demanda versava sobre o possível cabimento de mandado de injunção ${ }^{5}$ para disciplinar a prática de greenwashing. O Ministro Gilmar Mendes julgou improcedente o mandado de injunção, mas fundamentou a sua decisão nos seguintes pontos:

Primeiramente, não haveria cabimento para o mandado de injunção, posto que o remédio constitucional visa garantir uma liberdade ou prerrogativa prevista na Constituição que não pode ser exercida por omissão legislativa. Nesse ponto, o ministro entendeu que já existe lei ordinário prevendo a prática da publicidade enganosa, artigo 37 da Lei 8.078/90.

Ademais, o artigo 220, §3º II da Constituição Federal estabelece que compete à lei federal "estabelecer os meios legais que garantam à pessoa e à família a possibilidade de se defenderem de programas ou programações de rádio e televisão que contrariem o disposto no

\footnotetext{
${ }^{5}$ Para Carlos Augusto Alcântara Machado, “o mandado de injunção e, assim, um meio viabilizador do exercício de direitos constantes da Constituição Federal que dependem de regulamentação. É um instrumento processual que visa conferir efetividade à constituição" $(1999$, p.141)
} 
art. 221, bem como da propaganda de produtos, práticas e serviços que possam ser nocivos à saúde e ao meio ambiente".

Assim, o Supremo Tribunal Federal entendeu que a prática do greenwashing estaria incluída na publicidade enganosa, razão pela qual o mandado de injunção foi julgado improcedente, mas sedimenta entendimento que classifica a prática como ilícita e plenamente regulada no ordenamento brasileiro, não se podendo falar em lacuna ou omissão, sequer matéria nova. Por isso o STF firmou entendimento de que a prática do greenwashing estaria vedada pela previsão legal no plano interno pelo direito do consumidor no artigo 37 da Lei $8.078 / 90$.

Assim sendo, a empresa tem o dever de informação clara e precisa sobre produtos e serviços, havendo um dever quanto à transparência e boa-fé sobre as informações dos produtos e serviços. Havendo descumprimento do dever de informação, surge a responsabilidade pela publicidade enganosa, ou seja, quando o empresário/fornecedor apresenta ao consumidor informações falsas.

Configuradas as consequências jurídicas no plano constitucional e do código do consumidor, resta ainda referir em relação ao tipo de responsabilidade prevista no código civil para a atividade empresarial. Estabelece o artigo 970, parágrafo único do Código Civil que a responsabilidade empresarial é objetiva

\section{(falar um pouco mais da responsabilidade objetiva)}

Também do ponto de vista do direito civil, Pagotto (2013, p. 49) apresenta uma análise quanto ao dever de boa-fé objetiva quando ocorre o greenwashing:

(...) as violações são cada vez mais frequentes, e o greenwashing, enquanto falsa propaganda ambiental, é uma violação ética por definição. Ao utilizá-lo como elemento de um determinado "discurso", uma instituição deliberadamente induz seus interlocutores ao erro, criando um conflito racional e comprometendo a autonomia e a coerência da escolha. (PAGOTTO, 2013, p. 49)

Observa-se que a matéria ventilada vem ganhando força, e por conta disso foi impetrado o mandado de injunção discutido acima, é a gravidade do Greenwashing que excede a relação meramente entre empresário e consumidor. Atualmente já se discute o meio 
ambiente como um sujeito de direitos ${ }^{6}$, ampliando a noção de alteridade para além dos outros sujeitos humanos, mas também para animais, ambiente, natureza, cultura, etc.

Entre as considerações filosóficas, merece destaque o enfoque na ética que a temática da responsabilidade exige. Por ética podemos entender o conjunto de ações e valores que correspondem a uma moral refletida. Por ética, consideramos necessariamente as relações intersubjetivas, portanto, entre sujeitos que representam o outro de cada um. Portanto, sou responsável pelo outro, e o outro o é por mim.

Esta dimensão intersubjetiva é completada também por uma concepção de mundo que, ampliando as formas de responsabilidade com o outro, implicam no reconhecimento de que somos responsáveis pelo próprio mundo e pelas condições de vida para as futuras gerações. Hans Jonas estabelece uma relação entre a ética e a responsabilidade e, em sua obra, adverte “(...) Age de tal maneira que os efeitos de tua ação sejam compatíveis com a permanência de uma vida humana autêntica, ou ainda, não ponhas em perigo a continuidade indefinida da humanidade. (...)" (JONAS, 2006,18p.).

Carvalho (2011, p. 118-120) apresenta a ideia de que a forma exploratória de tratar o meio ambiente como um instrumento para o desenvolvimento econômico tem gerado consequências desastrosas. A capacidade da natureza se renovar não é infinita. As espécies extintas e em extinção pela atividade homem são uma prova disso. Neste sentido, os modelos de desenvolvimento devem primar pela sustentabilidade de recursos e práticas para garantir, de fato, a sobrevida na terra.

Por isso, não se pode olvidar que estas condições estão intimamente relacionadas como o sistema econômico que praticamos, e com as práticas empresariais do mundo neoliberal capitalista. Garantir uma reflexão ética e responsável é um ponto de partida necessário para o enfrentamento do greenwashing.

\section{Enfrentamento da prática do Greenwashing: um longo caminho}

Confundir o Greenwashing com mera publicidade enganosa é prejudicial, posto que, a responsabilização por publicidade enganosa é voltada apenas para o consumidor. As respostas que o código do consumidor oferecem são de reparação ao indivíduo lesado, sobretudo. No entanto, esta prática transcende o dano aos indivíduos que consomem os produtos maquiados.

\footnotetext{
${ }^{6}$ STONE, Christopher D. Should tree have standing? Toward legal rights for natural objects. Palo Alto: Tioga, 1988.
} 
Ela afeta diretamente o meio ambiente, a natureza, a coletividade de tal maneira que a reparação se torna muito mais complexa.

Nesse sentido, Stone (1988) estabelece que é necessário elevar o meio ambiente à categoria de sujeito de direitos para que por si só possa pleitear direitos e proteger-se. O autor ainda alerta que tratar o meio ambiente como objeto de direitos possibilita a sua negociação/comercialização e uma proteção plena só seria alcançada ao tratar o meio ambiente como um sujeito de direitos.

Por ora, tendo em vista a inexistência de lei federal que discipline especificamente o greenwashing, o Conar vem tentando disciplinar em nível interno, portanto, dando um tratamento específico de publicidade enganosa. Segundo Fialho, Marquesan e Souza (2015, p. 7) o CONAR vem tentando coibir as práticas de publicidade enganosa e abusiva, bem como o Greenwashing, desta forma:

\begin{abstract}
“(...) o órgão definiu alguns princípios que devem ser respeitados para veiculação de propagandas que queiram abordar o tema sustentabilidade, entre eles estão: veracidade (as informações devem ser verdadeiras, passíveis de verificação e de comprovação); comprovação e fontes (os responsáveis pelo anúncio deverão dispor de dados comprobatórios e de fontes externas que evidenciem as informações anunciadas, via site, Serviço de Atendimento ao Consumidor [SAC], e outros meios e materiais); concretude (se devem evitar conceitos vagos ou ambíguos sobre os benefícios socioambientais adotados). (...)"
\end{abstract}

A empresa brasileira Marketing Analysis (2015) publicou em 2015 um estudo sobre o greenwashing no Brasil que nos dá uma ideia de como o assunto não é pontual ou excepcional, mas de como deve se constituir, neta lógica do mercado, uma preocupação forte em termos de práticas empresariais:

(...) Em menos de cinco anos, a quantidade de produtos que se autodeclaram "verdes" cresceu quase cinco vezes (478\%) e o número total de embalagens com sinais e mensagens indicando posturas simpáticas com o meio ambiente disponíveis para o consumidor cresceu três vezes $(296 \%)$. (...)

A Marketing Analysis (2014) já havia publicado em 2014 outro estudo sobre o greenwashing no Brasil, reforçando que é mais comum o próprio produto se auto intitular verde, do que obter certificações de terceiros: 
“(...) Mas somente 5\% dos apelos correspondem a selos ou certificações de terceira parte. Ou seja, a rotulagem ambiental ainda é fundamentalmente baseada em autodeclarações. (...)Apenas 7\% dos produtos "verdes" encontrados apresentava algum tipo de certificação ou endosso de terceira parte. Os selos originais correspondem a $5 \%$ do total de apelos. (...)"

Portanto, resta evidenciado que não há uma prática concreta de certificações e isso se deve, em parte, à falta de conhecimento por parte do consumidor, na hora de checar as informações da embalagem e do seu produto e exigir uma maior transparência por parte dos produtores. Neste ponto, nunca é demais lembrar que as empresas muitas vezes fazem lobby para evitar que a legislação as obrigue a divulgar informações de seus produtos, como no caso da indicação de uso de produtos transgênicos..

No plano internacional o debate sobre o greenwashing é ventilado pelas Organizações não governamentais, porém não há regulamentação por meio de tratados ou convenções.

Angelo (2012) resume de forma objetiva a trajetória do greenwashing no plano externo:

(...) O ativista americano Kenny Bruno é um sujeito meio anônimo até mesmo no mundo ambiental. Mas pouca gente ignora hoje a expressão que ele lançou: "greenwash", ou maquiagem verde. O conceito foi difundido durante a Eco-92, em um documento feito por ele para o Greenpeace. O relatório denunciava a indústria química por fazer propaganda de ações "verdes" para disfarçar práticas que, na verdade, eram pouco sustentáveis. A expressão acabou entrando para o dicionário de Oxford em 2000. Em 2002, durante a conferência de Johannesburgo, Bruno voltou à carga, denunciando parcerias entre empresas com práticas trabalhistas pouco corretas e as Nações Unidas, o que foi chamado de "bluewash" (devido ao azul, cor oficial da ONU). (...) (ANGELO, 2012)

Segundo Pagotto (2013, p. 53) o Conar editou um guia verde seguindo a mesma estratégia de países como Estados Unidos, Canadá, Austrália e Dinamarca, consistindo em um manual com diretrizes/recomendações a serem seguidas por publicitários e consumidores.

Existem instrumentos para discutir judicialmente o greenwashing, ao menos no plano interno, seja pela via da publicidade enganosa, seja pela via da responsabilidade civil pelo dano ambiental.

Contudo o tema ainda padece de mais discussões e isso ainda é agravado pelo processo de desinformação que os meios de comunicação de massa acabam gerando no interesse dos grandes grupos econômicos. Portanto, para evitar o problema do greenwashing é 
necessário conferir ao meio ambiente a categoria de sujeito de direitos e um maior envolvimento da sociedade civil.

\section{Considerações Finais}

A preocupação em apresentar formas de evitar o greenwashing é cada vez mais presente ao redor do mundo e se faz necessário criar instrumentos que tragam respostas mais contundentes e aplicação eficaz.

Verifica-se que o greenwashing se prolifera com a sociedade de consumo e com o capitalismo neoliberal. No entanto, esta prática odiosa não podem ter o aval ou a naturalização dos que colocam o mercado e o lucro acima das pessoas, da dignidade da vida e do meio ambiente.

Embora o debate sobre o falso marketing verde no Brasil tenha se iniciado durante a Eco-92 e vem ganhando cada vez mais força, observa-se que não há ainda efetividade na responsabilização empresarial, tendo em vista o grande número de empresas que praticam a publicidade verde sem qualquer certificação.

Isto acaba acontecendo por conta do pequeno número de consumidores conscientes que buscam informações quanto às práticas das empresas e pelo processo eficaz de desinformação que as grandes empresas realizam.

Por outro lado, através da Ecopropaganda, com transparência e dados verdadeiros, esses consumidores teriam mais informações sobre o greenwashing e poderiam evitar o consumo de produtos/serviços sem certificação, obrigando os empresários a se adequarem para conseguir tais selos de certificação. Mas, se o preço dos produtos estiver afetado por tais certificações, certamente muitos consumidores, num país que perpetua desigualdades econômicas, sociais e de acesso a bens e oportunidades, ficariam reféns, de qualquer maneira, de produtos de baixa qualidade, ou verdadeiramente nocivos à saúde bem estar do consumidor.

A discussão foi levada ao Supremo Tribunal Federal por meio de mandado de injunção a fim de obter provimento jurisdicional no sentido de regulamentar o greenwashing, contudo a corte entendeu que tal prática seria uma forma de publicidade abusiva, julgado improcedente o mandado de injunção. 
Vale destacar que a responsabilidade pela publicidade abusiva protege apenas o consumidor e como dito acima, o falso marketing verde também implica em danos ao meio ambiente. Por conta disso, busca-se uma maior responsabilidade empresarial e uma regulamentação sobre a prática.

Em que pese não haja ainda um regulamento sobre o greenwashing, existem meios para trazer responsabilidade aos empresários que o praticam, seja através dos consumidores pleiteando a responsabilidade civil pela publicidade enganosa, seja através dos danos ambientais eventualmente causados pela ausência de ações que resguardem a integridade do meio ambiente.

É preciso enfrentar o greenwashing - marketing verde vazio, configurando-o como uma prática antiética, ilegal e lesiva aos indivíduos e a todo o meio ambiente.

\section{Referências}

ALEJARRA, Luis Eduardo Oliveira. A importância da assembleia geral de credores na recuperação judicial de empresas. In: Âmbito Jurídico, Rio Grande, XVII, n. 126, jul 2014. Disponível em: < http://ambito-juridico.com.br/site/?n_link=revista_artigos_leitura\&artigo_id=14197 >. Acesso em jun 2016.

ANGELO, Claudio. Da maquiagem verde ao 'reino da baboseira'. Folha de São Paulo. 2012. Disponível em: http://www1.folha.uol.com.br/fsp/especial/46904-da-maquiagem-verdeao-reino-da-baboseira.shtml . Acesso em 29 nov. 16

ANTONIOLLI, Gabriel Otávio; DIAS, Sylmara Lopes Francelino Gonçalves. Uma discussão em torno de Responsabilidades, Comunicação Ambiental e Greenwashing: o caso Petrobras. Organizações e Sustentabilidade, v. 3, n. 1, 2015. Disponível em: < http://www.teses.usp.br/teses/disponiveis/100/100134/tde-22072013-141652/en.php>. Acesso em 28 nov 2016.

ARAÚJO, Thiago Cássio D’Ávila . Ecoturismo ou Greenwashing? Revista ECO 21. Edição 129. Agosto de 2007. Disponível em <http://www.eco21.com.br/textos/textos.asp?ID=1607>. Acesso em: 28 de nov de 2016.

BRASIL. Supremo Tribunal Federal. Acórdão no Mandado de Injunção n.4766/DF. Relator: MENDES, Gilmar. Publicado no DJ de 07/03/2013. Disponível em http://www.Supremo Tribunal

Federal.jus.br/portal/jurisprudencia/listarJurisprudencia.asp?s1=\%28MI\%24\%2ESCLA\%2E+ $\mathrm{E}+4766 \% 2 \mathrm{ENUME} \% 2 \mathrm{E} \% 29+\mathrm{NAO}+\mathrm{S} \% 2 \mathrm{EPRES} \% 2 \mathrm{E} \&$ base=baseMonocraticas\&url=http://ti nyurl.com/cbjxkrm. Acessado em 01-12-2016. 
CARVALHO, Edson Ferreira de. Meio ambiente e direitos humanos. 2. ed. Curitiba: Juruá, 2011.

COELHO, Fábio Ulhoa. Curso de direito comercial, volume 1: direito em empresa. 16. ed. São Paulo: Saraiva, 2014.

CAMPOS, Adriana; ARDISSON, Daniel Piovanelli. Por uma nova concepção jurídica de empresa no marco da sociedade do risco: do lucro inconsequente à responsabilidade socioambiental. Sequência (Florianópolis), Florianópolis, n. 64, p. 85-104, July 2012. Available from <http://www.scielo.br/scielo.php?script=sci_arttext\&pid=S2177$70552012000100005 \& \operatorname{lng}=e n \& n r m=i s o>$. access on 16 June 2016.

DAWKINS, Richard. O Gene Egoísta; Tradução Geraldo H. M Florsheim - Editora Itatiaia Limitada, Belo Horizonte/MG, 1979.

FABRIANI, Carmen Beatriz; OLIVEIRA, Luciel Henrique de; PEREIRA, Adolfo Plínio. A responsabilidade social empresarial como estratégia para o desenvolvimento sustentável de negócios: o caso da Klabin s/a. Economia \& Pesquisa v. 12, n.12, p. 32 - 69 , novembro 2010. Disponível em: <

http://www.feata.edu.br/downloads/revistas/economiaepesquisa/v12_artigo02_responsabilida de.pdf $>$. Acesso em out 2016.

FERREIRA, Giselle Gama Torres. A publicitarização do" discurso verde" no cinema de longa-metragem de animação a partir do século XXI: greenmarketing ou greenwashing?. 2013. Disponível em: <

http://www.pantheon.ufrj.br/bitstream/11422/291/1/Giselle\%20GTorres\%20Ferreira\%20\%20Monografia.pdf>. Acesso em 28 nov 2016.

FIALHO, LETÍCIA DE SOUSA; MARQUESAN, FÁBIO FREITAS SCHILLING; DE SOUZA, LUCAS. GREENWASHING: CRÍTICA AOS APELOS "SUSTENTÁVEIS" DAS ORGANIZAÇÕES NOS MEIOS DE COMUNICAÇÃO PUBLICITÁRIOS. Anais do IV SINGEP - São Paulo-SP - Brasil - 08, 09 e 10/11/2015. Disponível em: < http://www.singep.org.br/4singep/resultado/614.pdf>. Acesso em 29 nov 2016.

JONAS, Hans. O princípio da responsabilidade: Ensaio de uma ética para a civilização tecnológica. Trad. Marijane Lisboa e Luiz B. Montes. Rio de Janeiro. PUC, 2006.

MACHADO, Carlos Augusto A. Mandado de Injunção, São Paulo: Atlas, 1999.

Market Analysis. GREENWASHING NO BRASIL: UM ESTUDO SOBRE OS APELOS AMBIENTAIS NOS RÓTULOS DOS PRODUTOS. 2014. Disponível em: < http://marketanalysis.com.br/wpcontent/uploads/2014/09/Greenwashing_2014_MarketAnalysis.pdf>. Acesso em 29 nov. 16.

Market Analysis. Greenwashing afeta 8 em cada 10 produtos vendidos no Brasil, e o uso de apelos ambientais pelas empresas torna-se mais estratégico e menos óbvio. 2015. Disponível em: <http://marketanalysis.com.br/wp-content/uploads/2015/06/Greenwashing-no- 
Brasil_20151.pdf>. Acesso em 29 nov. 16.

PAGOTTO, Erico Luciano. Greenwashing: os conflitos éticos da propaganda ambiental. 2013. Tese de Doutorado. Universidade de São Paulo. Disponível em: http://www.teses.usp.br/teses/disponiveis/100/100134/tde-22072013-141652/en.php>. Acesso em: 28 nov. 2016.

SAYEG, Ricardo; BALERA, Wagner. O capitalismo humanista. Petrópolis: Editora KBR, 2011.

STONE, Christopher D. Should tree have standing? Toward legal rights for natural objects. Palo Alto: Tioga, 1988. Disponível em

<http://isites.harvard.edu/fs/docs/icb.topic498371.files/Stone.Trees_Standing.pdf>.

TOMAZETTE, Marlon. A teoria da empresa: o novo Direito "Comercial". Revista Jus

Navigandi, Teresina, ano 7, n. 56, 1 abr. 2002. Disponível

em: <http://jus.com.br/artigos/2899>. Acesso em: 26 mar. 2015. 